\title{
非相溶系ポリマーブレンドの分散構造への溶融-固化過程における 冷却方法の影響
}

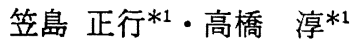

(受付 1983 年 4 月 28 日・審査終了 1983 年 8 月 18 日)

\begin{abstract}
要 旨 非相溶系ポリマーブレンドの溶融状態から固化状態への冷却方法とモルホロジーとの関倸 を調べた。椧却方法は, 溶融状態の試料を液体窒素中に浸し急椧する方法と, 室温中で椧却を行う方 法である。モルホロジーの観察は走査型電子顕微鏡で行った。試料はポリプロピレン樹脂 $(\mathrm{PP}) \cdot x タ$ クリル楖脂 (PMMA), 高密度ポリエチレン樹脂 (HDPE).PMMA，そしてPP・ポリスチレン樹脂 (PS) 試料の各組合せである。いずれの陚料に扔い一も混合率 $(c)=0.25 に$ に㧍いて, 泠却方法の相違 によるモルホロジー変化が顕著に生じた. HDPE·PMMA 及びPP.PS 試料の $c=0.50$ では，混練 温度が高くなるほど，また，急椧よりも徐泠の場合の方が分散相の寸法は大きくなった。
\end{abstract}

\section{1 緒言}

異種高分子の混合は品質改良，資源の有効利用，廃棄 物処理などの観点より関心が持たれており，その物性に

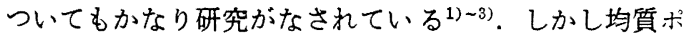
リマーと比べ，複雑な挙動を示す場合が多い，例えば機 戌的に混合した非相溶系ポリマーブレンドにおいては, 機械的性質(2),8)や，流動物性(3)-15) とついて加成性が成り 立たない場合が多い，しかも加成性からのずれは，組み 合わせるポリマーの種類や外的操作条件によって变化す る. 特に溶融状態において, 特異流動挙動 $\left.{ }^{10)}, 15\right)$, 特異 混練挙動 ${ }^{(8)}$,17), 特異流れ指数举動 ${ }^{12), 14)}$ のような非常に

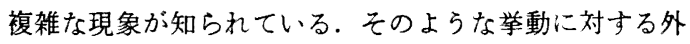
的操作条件とモルホロジー19)の関保については，まだ明 らかでないことが多い，本報では，溶融一固化過程での 冾却方法の違いが及ぼすモルホロジーへの影響について 検討した。このような溶融一固化過程での泠却方法とモ ルホロジーとの関倸についての知見は, 前述の複雑な流 動機構の解明のみならず，積極的なモルホロジー制御と いら観点からも有意義であると考えられる.

\section{2 実験}

\section{1 試料}

使用した試料は，ポリプロピレン樹脂（PP，三井東圧 化学(株) 製 NOBLEN $\cdot J H-G, M I=4 \mathrm{~g} / 10 \mathrm{~min}$ ), 高密度 ポリエチレン樹脂 (HDPE, 旭化成工業(株) 製 SUNTEC $. \mathrm{J} 241, \mathrm{MI}=5 \mathrm{~g} / 10 \mathrm{~min}$ ), メタクリル樹脂 (PMMA，協 和ガス(株) 製 PARAPET.G1000, MI = $8.5 \mathrm{~g} / 10 \mathrm{~min}$ ),

*1 法政大学工学部機械工学科 (函184 小金井市梶野町 3-7-2)
そしてポリスチレン樹脂 (PS，新日本製鉄化学(株) 製 ESTYLENE.G20, MI $=11.5 \mathrm{~g} / 10 \mathrm{~min})$ の 4 種類であ る. ブレンドの組合せとして, PP と PMMA, HDPE と PMMA, そして PP と PSを選んた。. 組合せ試料の 表示の仕方は前報8) 15) に用いた方法によりメルトイン デックス (MI) 值の小さい方の試料を先に表示した．混 合割合は前報8),10) で定義した混合率 (c) で表した。これ は組合せ試料名の先に表示した成分の重量分率で表する のである。

\section{2 実験方法}

混合試料作製のためにはラポプラストミル（(株) 東洋 精機製作所製 10-200-T形，ミキ甘ー容量 $60 \mathrm{cc}$ ) を用い た．Fig. 1 にこのプラストミルを用いて測定した，そ れぞれの成分試料の混練抵抗 $(M)$-混練温度 $\left(T_{\mathrm{M}}\right)$ 線図 を示す，それぞれの成分試料の線図は互いに交差してい る.つまり上述の 3 対の組合せにおいては $T_{\mathrm{M}}$ が変化す ると両成分の $M$ の值の大小関係も変化する. このよう に両成分の粘性の大小関係が変化する場合, これに伴い 相構造に大きな変化が起こることがある ${ }^{18) ~ 21)}$.このこと から各混合試料の作製時の $T_{M}$ は, 交点付近の $T_{\mathrm{M}}$ を 基準にそれと上下各 $20^{\circ} \mathrm{C}$ 離れた三つの温度とした。 た だし PP と PS の組合せでは, 装置の制約上から交点 以上の $T_{\mathrm{M}}$ においてのみ混練を実施した。

混合試料の作製手順は次のようにした。そそれぞれの成 分試料をぺレット状態で計量し，あらかじめペレット同 士を混合した後, $T_{\mathrm{M}}$ よりも $30^{\circ} \mathrm{C}$ 低く設定したラボプ ラストミルのミキサーに投入する.10分間の予熱後, あ らかじめ決めた $T_{\mathrm{M}}$ になるよら温度制御しながら，ロー ター回転数 $100 \mathrm{rpm} て ゙ 10$ 分間混練を行った。混練温 度より低い温度で予熱を行う理由は, 混練開始時のせん 


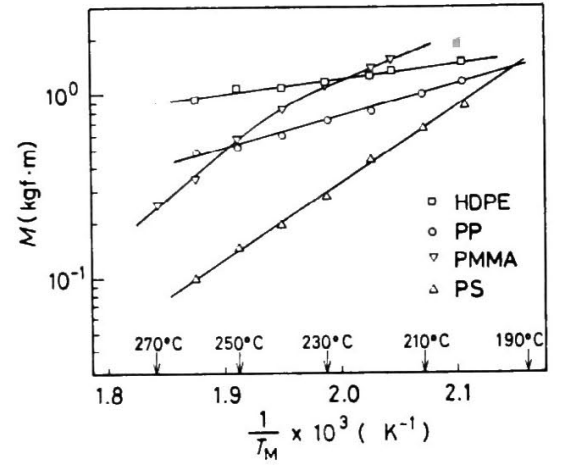

Fig. 1. Relationship between kneading torque $(M)$ and kneading temperature $\left(T_{\mathrm{M}}\right)$ at kneading time $\left(t_{\mathrm{M}}\right)=10 \mathrm{~min}$ for HDPE, PP, PMMA, and PS.

断摩擦による発熱分を見越して温度制御を行らためであ $\left.ろ^{16)}, 17\right)$.

混練終了後, 直ちに試料をラボプラストミルのミキサ 一より取り出し, 液体窒素 (沸点: $-195.8^{\circ} \mathrm{C}$ ) 中に浸し 冷却を行う。これを本報では“急冷”と称する。またる う一つの方法は混練終了後, 直ちにヒータ一電源を切 り, 試料をミキサー中に入れたまま, 試料を取り出し可 能な限界まで冷却した後, 取り出す. その後これを室温 中に放置し冷却する.この方法を“徐冷”と称する. “急冷”, “徐冷”における冷却速度は, 試料の種類や, その量などによりいくぶん異なるか゚, 急冷の場合 40 $10^{\circ} \mathrm{C} / \mathrm{s}$ の範囲に, 徐彾の場合ミキサー中で $0.2 \sim 0.07^{\circ} \mathrm{C} / \mathrm{s}$, ミキサーより取り出し後 $1 \sim 0.5^{\circ} \mathrm{C}$ である.

このようにして作製した混合試料を走査型電子顕微鏡 (日本電子 (株) 製 JSM-35) で観察するが，そのための観 察試料とするために次の処理を施した. 各混合試料を切 断し，その切断面を鏡面仕上げし溶剤処理を行った後， イオンスパッタリング装置で $\mathrm{Au}$ 蒸着を施す.この溶剤 処理では混合試料中の片方の成分だけを溶出する溶剂を 使用する.このため溶出しない成分から成る相の形態が 現れるので，ある相がどの成分でできているかを判断す ることができる. 溶阂処理方法は種々検討した結果, 次 のような超音波照射下における段階的な溶剤処理方法が 最も良好であることを見いだし用いた，各組合せ試料共 $c=0.25$ の混合試料には溶剂にベンジルアルコールとェ チルアルコールを使用し, 前者による処理を 30 秒行っ た後, 後者による処理を 1 分行い, これを4回繰り返し た。 また他の混合率の試料には, 溶剤にキンレンとベン ジンを使用し, 前者により 6 分, 後者により 1 分の処理 を行った. いずれの処理法でも前者の溶剤は可溶成分の 溶出のため, 後者の溶剂はその溶出した成分の試料表面

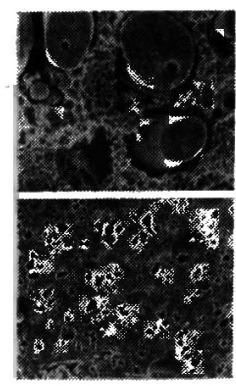

$T_{M}=230^{\circ} \mathrm{C}$

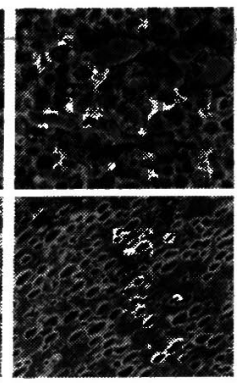

$T_{M}=250^{\circ} \mathrm{C}$

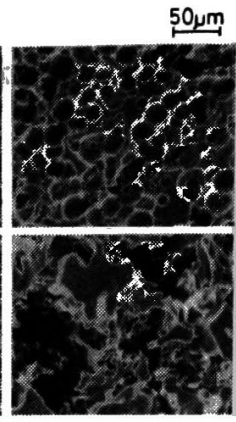

$T_{M}=270^{\circ} \mathrm{C}$
Fig. 2. Scanning electron micrographs of PP. PMMA blends of $(c)=0.25$ kneaded at various temperatures $\left(T_{\mathrm{M}}\right)$ : upper, fast cooling; lower, slow cooling.

からの除去, 洗浄のため使用した.このため後者の溶剤 は溶出能力が前者よりも劣るものを使用した．また超音 波照射により溶出の促進とともに溶出物の試料表面から の除去を積極的に行うことができる．このような二重の 処理により溶出物は, ほぼ完全に試料表面から除去でき る.

当研究で使用した溶剤処理法は $\mathrm{Han}^{(3)}$ らも行ってい る方法であるが，切断面を表面処理することによる表面 構造の変質の可能性は, 試料を割り, その破断面を観察 する方法に比べるといくぶん大きい場合すあるかと思わ れる.それはミクロトームのよらな鋭利な刃物で切断し た場合でも試料の切削性によってはパリやササクレが出 る場合があり，このままでは観察できないことがある. しかしそのような時でもエメリペーパを使用し研磨面が 過熱しないように注意深く鏡面仕上け゚することにより観 察可能な状態にできる。また溶剂による溶出は，溶出能 カと処理時間を適切に組合せないと, 表面構造を変質さ せることがある. 溶出する成分の方が多く含まれる混合 試料では溶出能力の強い溶剤を使うと浸食が強過ざ溶剤 中で試料が壊れることがある.このような試料には溶出 能力の弱い溶剤を使用し洗浄を繰り返す必要がある.c $=0.25$ のみ他と異なる処理を施したのは, この理由に よる.

\section{3 結果と考察}

\subsection{PP.PMMA 試料}

PP.PMMA 試料の混合率 $(c)=0.25$ における電子顕 微鏡写真を Fig. 2 に示す. 写真の左端が混練温度 $\left(T_{\mathrm{M}}\right)$ $=230^{\circ} \mathrm{C}$ で混練したものであり，中央が $T_{\mathrm{M}}=250^{\circ} \mathrm{C}$, そ して右端が $T_{\mathrm{M}}=270^{\circ} \mathrm{C}$ である. いずれる上段が液体窒 素中で急冷したもの，下段が室温中で徐冷したものであ る. 以後出てくる顕微鏡写真も, 縦列ごとの $T_{\mathrm{M}}$ は異な 
っても上段が急冷したもの, 下段が徐冷したものとして 表示する. Fig. 2 において急冷の 3 枚を比べると $T_{\mathrm{M}}=$ $230^{\circ} \mathrm{C}$ において見られるよらな塊は $T_{\mathrm{M}}$ が高くなるはど 細化しているのが分かる． $T_{\mathrm{M}}$ が高くなるほど混練抵抗 (M) が減少し流動性が良くなる結果, 混練されやすく なるため塊が細化するのであるう．これらの罒に打いて 溶出しない大きな塊はPP から成る分散相であり， PMMA が連続相となっていると考兄られる.

Fig. 2 の下段は混練後徐冷したもので, 上段の急冷と 比べると全く様相が異なっている。これは冷却過程中に 大きなモルホロジー変化が起きていることを示してい る. 特に $T_{\mathrm{M}}=270^{\circ} \mathrm{C}$ では両成分共, 連続相であり, 両 連続相間の界面は複雑に入り組んでいる. 両成分共連続 相になるのは溶融一固化過程での流動可能な時間が他の $T_{\mathrm{M}}$ のものや急冷した場合と比べ長いため, 初めに分散 相が存在していても，分散相同士がその間に凝集する結 果, 両成分とも連続相となると考えられる． $T_{\mathrm{M}}=230^{\circ} \mathrm{C}$ では穴は分散相のPP の脱落により生じたものと考えら れる. $T_{\mathrm{M}}=250^{\circ} \mathrm{C}$ になるとこの PP 分散相の寸法は大 きくなる. 機械的混合操作によるブレンドは, エネルギ 一を与えて無理やり分散混合させており, その状態は,

必ずしも安定であるとは言兄ない，そのために混合を停 止すると, 安定な平衡状態に戻万らとして分散構造の変 化を起こすと考えられる. 特に $T_{\mathrm{M}}$ の高い場合ほど, 固 化するまでの流動可能な時間が長く与えられ, 分散相の 会合の機会も増える. その結果, 凝集が起こるなどモル ホロジー変化はより大きなものとなる，このことから， これらの挙動は徐冷時の冷却に要する時間を長くするほ ど顕著になると言党る.

冷却方法の違いによって起こる分散構造变化を伴なら 大規模なモルホロジー変化は後項にも述べるように, 当 実験ではどの組合せ試料も $c=0.25$ で生じる. Nielsen の相反転が起きる場合の混合則22)における相反転領域 が，本報の組合せ試料の場合 $c=0.25$ において存在する ため, このcに打ける分散構造は, 構造变化を起こし やすい状態となっている. そして $T_{\mathrm{M}}$ や泠却条件によ り, 冷却時間が長く与兄られるよらな場合ほど, エネル ギー的により安定な状態になろらとするため, 分散構造 が大きく変化すると予想される.

次に $c=0.50$ の場合を Fig. 3 に示す. 試料表面に見 壳る穴はすへて浅いくぼみ状で，その縁はなだらかで, 溶剤で浸食された跡のようである. また穴となっていな い円形状の部分があり, その表面にはエメリペーパの跡 と思われる傷が残っている.このことからこの部分は溶 出しない方の成分からできていることが分かる。〈ぼみ 状の穴はこの不溶な分散相が脱落した跡であり, 連続相 部分は溶出する成分からなるすのと考兄られる. 以上よ り, 溶剤に不溶な PP が分散相, 可溶な PMMA が連

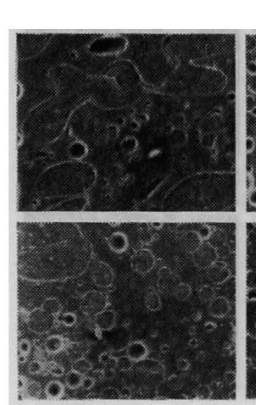

$T_{M}=230^{\circ} \mathrm{C}$
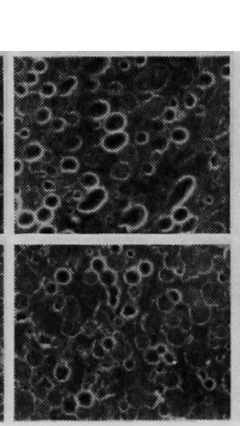

$T_{M}=250^{\circ} \mathrm{C}$

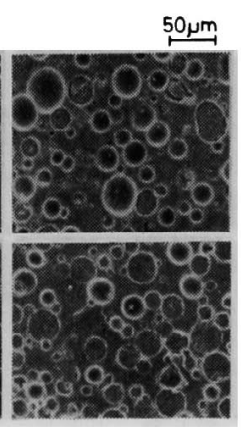

$T_{M}=270^{\circ} \mathrm{C}$
Fig. 3. Scanning electron micrographs of PP. PMMA blends of $(c)=0.50$ kneaded at various temperatures $\left(T_{M}\right)$ : upper, fast cooling; lower, slow cooling.

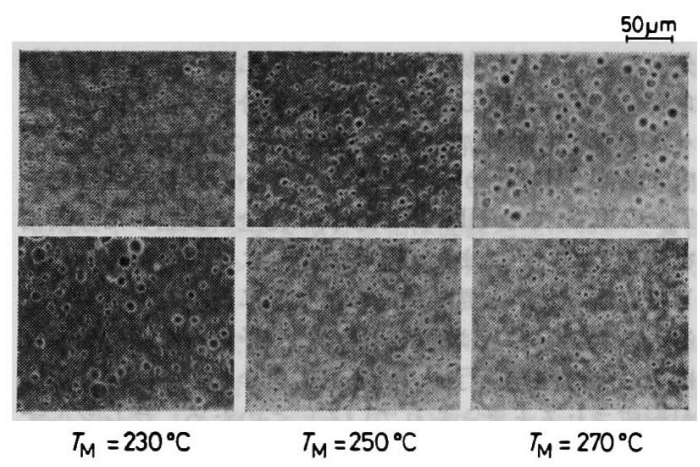

Fig. 4. Scanning electron micrographs of PP. PMMA blends of $(c)=0.75$ kneaded at various temperatures $\left(T_{\mathrm{M}}\right)$ : upper, fast cooling; lower slow cooling.

続相になっていると判断される.急冷の場合 $T_{\mathrm{II}}$ が低い と, 分散相の形はあたか子餅を引き延ばし円形状に引き ちぎられる前のよらないびつなものであり，混合があま り進んでいないことを示している. 徐冷した場合でも分 散相の形が球に近付く他は大きな変化はない. $c=0.25$ に比べ $c=0.50$ では, 分散形態が冷却速度にさほど依存 しない.

$c=0.75$ の場合を Fig. 4 に示すが, ここではPMMA が分散相で溶出して穴となり PP が連続相となっている と考えられる. $c=0.75$ では $c=0.25$ に比べて $T_{\mathrm{M}}$ や 冷却方法の変化による分散相の形や大きさの変化は小さ い.

\subsection{HDPE PMMA 試料}

HDPE.PMMA 試料の $c=0.25$ における電子䫒微鏡

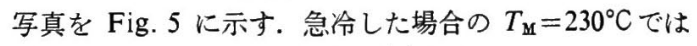
HDPE が分散相, PMMA が連続相となっている.つ 


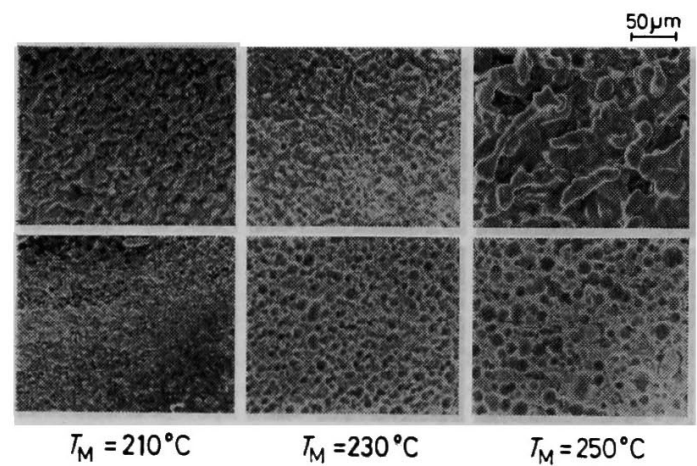

Fig. 5. Scanning electron micrographs of HDPE.PMMA blends of $(c)=0.25$ kneaded at various temperatures $\left(T_{\mathbf{M}}\right)$ : upper, fast cooling; lower, slow cooling.

まり連続相の PMMA が溶出することによって HDPE 分散相の脱落した跡が浅いくぼみ状に残っていると考兄 られる. $T_{\mathrm{M}}=210^{\circ} \mathrm{C}, 250^{\circ} \mathrm{C}$ では両成分共一見連続相のよ らにも見えるが，溶出する PMMA の溶出体積分を考 慮すれば HDPE が分散相となっていると判断される。 $T_{\mathrm{M}}=230^{\circ} \mathrm{C}$ では HDPE の形状は完全に独立した分散相 を形成している. また $T_{M}=250^{\circ} \mathrm{C}$ よりる分散相が細化 していることから混練が進んだ状態にあることが分か る. 練りブレンドは溶融状態の高分子材料を機械的混合 により分散操作を行い, 練り応力を介して分散混合形態 が形成されると考えられている。このため，ブレンドす る成分試料同士が似たレオロジー的性質を持っていない と, 練り応力が均一に伝わらず不均質なブレンド物とな る場合がある ${ }^{23)}$ ．まだ゙ムブレンドにおいて，プレンド される成分同士の粘度比が 1 亿近いほど, 分散単位が小 さく, 粘度比の違いによって分散相, 連続相が反転する ようになる24) との報告もある. HDPE.PMMA 試料に おける成分試料では $T_{M}=230^{\circ} \mathrm{C}$ で両成分の $M$ の値が ほぼ同じであり (Fig. 1), 混練応力が最も効率的に层え られると考学られる. $T_{\mathrm{M}}=250^{\circ} \mathrm{C}$ になると両成分の $M$ の差が大きくなり混練が効率的になされないため分散相 サイズが大きくなるのであろう．また $T_{\mathrm{M}}$ が高くなると 流動性が良くなるため分散相同土が会合しやすくなる. このことから $T_{\mathrm{M}}=210^{\circ} \mathrm{C}$ と $250^{\circ} \mathrm{C}$ では流動性の良い $T_{\mathrm{M}}=250^{\circ} \mathrm{C}$ の方が分散相が大きくなることが説明され 万.

徐冷した場合の写真の穴は HDPE が脱落したもので あり, HDPE が分散相, PMMA が連続相の形態をな していると考兄られる. $T_{\mathrm{M}}=210^{\circ} \mathrm{C}$ と $250^{\circ} \mathrm{C}$ を比較す るとモルホロジー的に大きく異なっていることが分か る. 両者には冷却時間の差の他に冷却開始時に持ってい る流動性の差がある. そのために徐冷時のモルホロジー

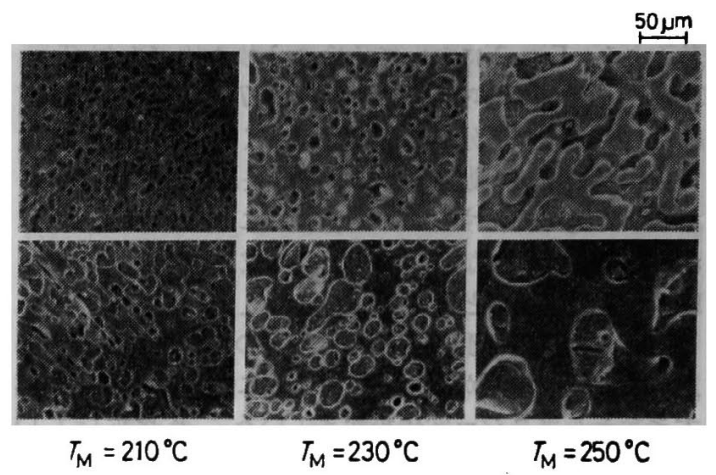

Fig. 6. Scanning electron micrographs of HDPE.PMMA blends of $(c)=0.50$ kneaded at various temperatures $\left(T_{\mathrm{M}}\right)$ : upper, fast cooling; lower, slow cooling.

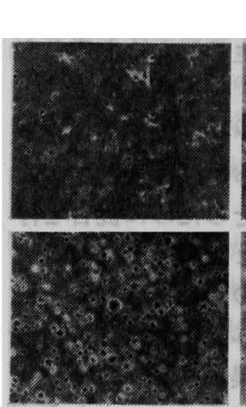

$T_{M}=210^{\circ} \mathrm{C}$

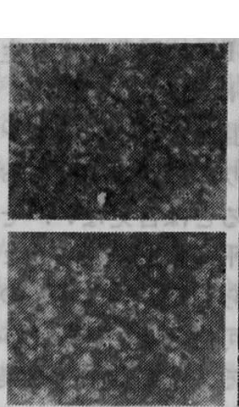

$T_{M}=230^{\circ} \mathrm{C}$

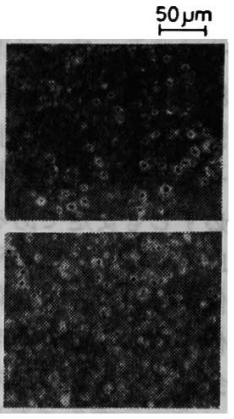

$T_{\mathrm{M}}=250^{\circ} \mathrm{C}$
Fig. 7. Scanning electron micrographs of HDPE. PMMA blends of $(c)=0.75$ kneaded at various temperatures $\left(T_{\mathrm{M}}\right)$ : upper, fast cooling; lower, slow cooling,

的変化挙動が異なってくるものと考えられる.

$c=0.50$ の場合を Fig. 6 に示す. いずれの場合も PMMA が分散相であり，溶出せずに残っている部分は HDPE であり連続相を成していると考えられる. 急冷, 徐冷共に $T_{\mathrm{M}}$ が高くなるほど, 分散相寸法は大きくな る. また，徐冷した方が急冷したものよりる分散相寸法 は大きい.つまり $T_{\mathrm{M}}$ が上昇し流動性が良くなる汪ど， また冷却時間が長く与えられるほど，分散相同士の会合 する機会が増えるために分散相の寸法が大きくなるもの と思われる.

Fig. 7 に $c=0.75$ に抢ける場合を示す. いずれる溶 出する PMMA が分散相, HDPE が連続相となってい ると考えられる. 分散相の寸法は $T_{\mathrm{M}}$ や冷却速度にほと んど影響されない。

\subsection{PP.PS 試料}

Fig. 8 は PP.PS 試料の $c=0.25$ に打けるあのであ 


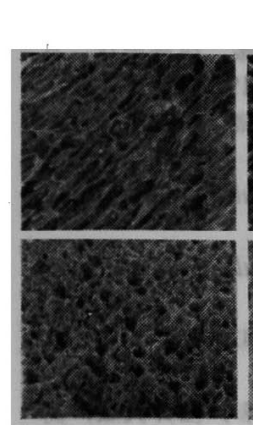

$T_{M}=190^{\circ} \mathrm{C}$

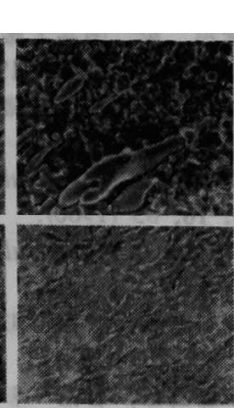

$T_{M}=210^{\circ} \mathrm{C}$

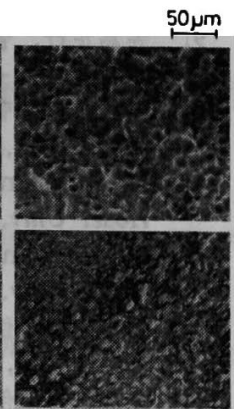

$T_{\mathrm{M}}=230^{\circ} \mathrm{C}$

Fig. 8. Scanning electron micrographs of PP. PS blends of $(c)=0.25$ kneaded at various temperatures $\left(T_{\mathbf{M}}\right)$ : upper, fast cooling; lower, slow cooling.

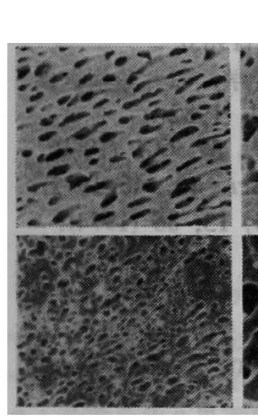

$T_{M}=190^{\circ} \mathrm{C}$

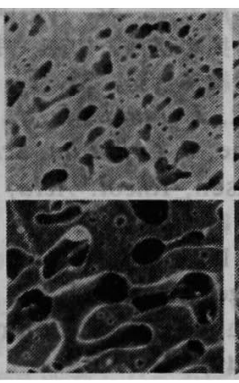

$T_{M}=210^{\circ} \mathrm{C}$

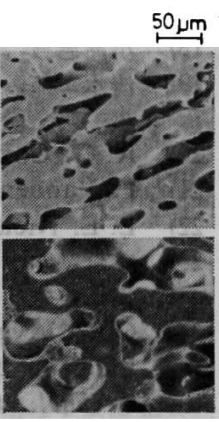

$T_{M}=230^{\circ} \mathrm{C}$

Fig. 9. Scanning electron micrographs of PP. PS blends of $(c)=0.50$ kneaded at various temperatures $\left(T_{\mathrm{M}}\right)$ : upper, fast cooling; lower, slow cooling.

る. 急冷での $T_{M}=190^{\circ} \mathrm{C}$ では両成分が連続相となり, 互いてからみあった網状の構造をしている. $T_{\mathrm{M}}=210^{\circ} \mathrm{C}$, $230^{\circ} \mathrm{C}$ では溶出しないPP が分散相, 溶出する PS が 連続相であると考えられる。

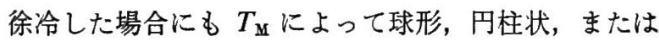
不規則な形状と異なってはいるが，基本的に塊の部分は 溶出しないPPであり，分散相を成しており，溶出する PS が連続相となっていると考えられる. 急冷と徐冷を 比べるとその構造は著しく異なる。これはそれぞれの冷 却法における冷却時間の差の影響を受けているものであ り，また $T_{\mathrm{M}}$ の変化によってもモルホロジーは変化して いる.つまり $c=0.25$ での混練中の分散構造は非常に不 安定なものと予想される.

$c=0.50$ の場合を Fig. 9 に示す。いずれにおいても， PS は分散相であり溶出して穴となり，PP が連続相とな っていると考えられる. 急冷の場合 $T_{\mathrm{M}}$ が高くなるほど,

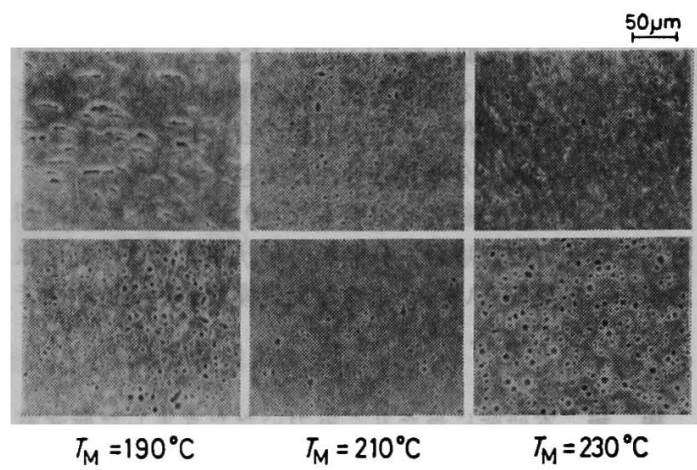

Fig. 10. Scanning electron micrographs of PP. PS blends of $(c)=0.75$ kneaded at various temperatures $\left(T_{\mathrm{M}}\right)$ : upper, fast cooling; lower, slow cooling.

分散相寸法は大きく, $T_{\mathrm{M}}=230^{\circ} \mathrm{C}$ では隣り合ら分散相が 接触しあっているものもある. 分散相寸法が大きくなる のは， $T_{\mathrm{M}}$ が高くなると流動性が良くなり，混練過程で の分散相の会合の機会が增えるためと考えられる. $T_{\mathbf{M}}=$ $210^{\circ} \mathrm{C}, 230^{\circ} \mathrm{C}$ では, 大きな分散相の他に小さな分散相が あるが，これらの小さな分散相は混練過程において会合 するに至らなかったものがそのまま残ったものと考光ら れる.

徐冷した場合でも $T_{\mathrm{M}}$ の上昇に伴い分散相の寸法が大 きくなり，隣り合らものと接するようになっている，急 冷と比べると, 徐冷の方が $T_{\mathrm{M}}$ が高くなるほど, 分相散 寸法の大きくなる割合が大きくなる．これらのことは $T_{M}$ が高い状態で, しかも流動可能な時間が長いほど, 分散相の凝集する程度が大きくなるためと考えられる。 このように $c=0.50$ では分散相の形状や大きさの変化は あるが相反転のよらな大規模な構造の变化は起こらな い.

$c=0.75$ の場合を Fig. 10 示す. ここでも溶剤に溶出 し穴となる部分は PS で分散相, そして PP が連続相 となっていると考えられる. 急冷の $T_{M}=190^{\circ} \mathrm{C}$ では不 規則な形であるが，他のものはすべて分散相は球形に近 い形状となっている.

\section{4 結論}

非相溶系ポリマープレンドの分散構造を, 溶融-固化 過程における冷却方法を変えて観察し検討した結果, 以 下のことが明らかになった。

(1) PP.PMMA, HDPE.PMMA, PP.PS 試料のい ずれも $c=0.25$ では $T_{\mathrm{M}}$ や冷却方法の変化によって, 分散構造が大きく変化する。これはこの混合率において 溶融時の分散混合状態が不安定な状態にあるためである 5 . 
(2) HDPE.PMMA, PP.PS 試料の $c=0.50$ では

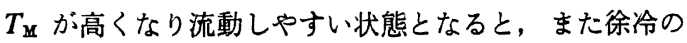
ように冷却に要する時間を長く取り冷却過程での流動で きる状態を長い間保つと, 分散相が会合して凝集して行 く傾向が見られ，分散相の寸法は大きくなって行く.

(3) いずれの組合せ試料も $c=0.50,0.75$ では冷却 方法を変化させた場合，分散相の形状や大きさの変化は あるが，相反転といったよらな大規模な分散構造の面で の変化は生じない.

謝辞 本研究に当たりご協力いただきました研究室 の諸氏に哚謝します。

\section{文献}

1) 日本化学会編, “複合材料”, 学会出版センター, 東京 (1975).

2) 西敏夫, 秋山三郎, 井上隆, “ポリマーブレ ンド”, シーエムシー, 東京 (1979).

3) 高分子学会編, “ポリマーアロイ”, 東京化学同 人, 東京 (1981).

4) 笠島正行, 福島邦博, 伊藤勝彦, 塑性と加工, 21, 239 (1980).

5) 笠島正行, 福島邦博, 伊藤勝彦, 高分子論文集, 38, 95 (1981).

6) C. D. Han, “Rheology in Polymer Processing ", Academic Press, New York (1976), p. 165 .

7) 小野木重治, 日本化学雑誌, 87, 1245 (1966).
8)笠島正行, 森 芳郎, 化学工学, 37, 915 (1973).

9) 笠島正行, 菅沼彰, 国井大蔵, 伊藤勝彦, 日 本レオロジー学会誌, 7, 27 (1979).

10）笠島正行，菅沼彰，国井大蔵，伊藤勝彦，高 分子論文集, 36, 481 (1979).

11) M. Kasajima and K. Ito, Bull. College Eng., Hosei Univ., 16, 85 (1980).

12) M. Kasajima and K. Ito, Bull. College Eng., Hosei Univ., 17, 11 (1981).

13）笠島正行, 伊藤勝彦, 菅沼 彰, 国井大藏, 高 分子論文集, 38, 239 (1981).

14）笠島正行，伊藤勝彦，菅沼 彰，国井大藏，高 分子論文集，38，245 (1981)。

15) 笠島正行, 伊藤勝彦, 菅沼 彰, 国井大藏, 高 分子論文集，38，253 (1981)。

16)笠島正行, 伊藤勝彦, 菅沼 彰, 国井大蔵, 高 分子論文集, 37, 41 (1980).

17) 笠島正行, 伊藤勝彦, 菅沼 彰, 国井大蔵, 高 分子論文集, 37, 419 (1980).

18) 小高忠男, 高分子, 32, 180 (1983).

19) 清水二郎, 奥居徳昌, 山本 学, 石井昌樹, 高 久 明, 繊維学会誌, 38, T1 (1982).

20) R. G. Cox, J. Fluid Mech., 37, 601 (1969).

21) H. Vanoene, J. Collid Int. Sci., 40, 448 (1972).

22) L. E. Nielsen, Rheol. Acta, 13, 86 (1974).

23）高分子学会編, “ポリマーアロイ”, 東京化学同 人, 東京 $(1981)$, p. 8.

24) G. N. Avgeropoulos, F. C. Weissert, P. H. Biddison, and G. G. A. Böhm, Rubber Chem. Technol., 49, 93 (1976).

Influence of Cooling Methods on the Two-Phases Structure of Incompatible Polymer Blends in the "Melt-Solidification Process"

Masayuki Kasajima*1 and Atushi TAKahashi*1

*1Department of Mechanical Engineering, College of Engineering, Hosei University (7-2, Kajinocho 3chome, Koganei, 184 Japan)

Relationships between morphology and method of cooling from molten state to solid state in incompatible polymer blends have been investigated. Two cooling methods are employed. One is the fast cooling method, immersing the sample in liquid nitrogen. The other is the slow cooling method, leaving the sample at room temperature. Morphologies of the polymer blends have been observed by a scanning electron microscope. The combinations of polymers in our blends are: polypropylene (PP) -polymethyle methacrylate (PMMA), high-density polyethylene (HDPE).PMMA, and PP.polystylene (PS). At weight fraction $(c)=0.25$, remarkable changes of the morphology were found. The higher the kneading temperature and the slower the cooling rate, the larger was the size of the dispersed phases in PP.PS and HDPE.PMMA blends of $c=0.50$.

KEY WORDS Morphology / Melt-Solidification / Phase Structure / Polymer Blend / Plastic Alloy / Resin Alloy / Cooling Rate /

[Kobunshi Ronbunshu, 40(10), 667-672 (1983)] 